\title{
Maquiavel Versus Rousseau: as Divisóes Sociais e Seu Papel em uma República Bem-Ordenada
} MACHIAVELLI VERSUS ROUSSEAU: THE SOCIAL DIVISIONS AND

\author{
THEIR ROLE IN A WELL-ORDERED REPUBLIC
}

Renato Moscateli ${ }^{1}$

\begin{abstract}
RESUMO: As relaçốes de conflito entre os grupos sociais constituem um tópico relevante para a filosofia política, e as maneiras distintas como elas são interpretadas dependem de uma visão mais ampla sobre as condiçốes apropriadas a um Estado bem-ordenado. Maquiavel, por exemplo, ao refletir sobre o caso da Roma Antiga, procurou refutar aqueles que condenavam os tumultos entre os nobres e a plebe da cidade, como se eles tivessem provocado apenas males à república. Para o autor, tais tumultos estavam entre as principais causas da liberdade romana, visto que a diferença nos "humores" dos grandes e do povo resultou em embates que deram origem às leis favoráveis à liberdade. Rousseau, por sua vez, descreveu a existência de "associaçóes particulares" dentro da sociedade civil como algo potencialmente nocivo à harmonia da república, pois cada uma delas contém um interesse particular passível de se sobrepor ao bem comum, nas deliberaçóes públicas, prejudicando o prevalecimento da vontade geral. Ainda para o genebrino, a ocorrência de longos debates e de tumultos nas assembleias populares poderia ser um sinal de divisóes internas capazes de ocasionar a ruína do Estado. Frente a essas duas maneiras de conceber o papel político dos conflitos sociais, o objetivo deste trabalho é realizar uma análise comparativa das ideias de Maquiavel e de Rousseau.
\end{abstract}

PALAVRAS-CHAVE: Maquiavel. Rousseau. República. Conflitos políticos.

As relaçóes de conflito que se dão entre os grupos sociais constituem um tópico relevante para a filosofia política, podendo-se compreendê-las, seja como um fator essencial na promoção da liberdade civil, seja como um obstáculo à coesão do corpo político, pois essas interpretaçôes distintas dependem de uma

${ }^{1}$ Doutor em Filosofia pela UNICAMP. Professor da Universidade Federal de Goiás e membro do Programa de Pós-Graduação em Filosofia da instituição. Escreveu os livros Rousseau frente ao legado de Montesquieu: História e teoria política no Século das Luzes (EDIPUCRS) e O Senhor das Letras: o Antigo Regime e a modernidade na literatura voltaireana (EDUEM). Atua na área de Filosofia Política, com ênfase em autores modernos, e também na área de História, com ênfase em História Intelectual. É coordenador do Grupo Interdisciplinar de Pesquisa Jean-Jacques Rousseau (UNICAMP), membro pesquisador do NEHRO - Núcleo de Estudos de História da Retórica e da Oratória Políticas (UEL) e do Grupo de Pesquisa Rousseau e a Filosofia Francesa do Iluminismo (UNIFESP). Também faz parte do núcleo de sustentação do GT Rousseau e o Iluminismo da ANPOF e do Conselho Diretor da Associação Brasileira de Estudos do Século XVIII (ABES18). E-mail: rmoscateli@hotmail.com

http://dx.doi.org/10.1590/S0101-317320150004000011 
visão mais ampla sobre as condiçôes apropriadas a um Estado bem-ordenado. Tendo isso em mente, o objetivo da presente exposiçáo é realizar uma análise comparativa das ideias de Maquiavel e de Rousseau quanto a esse tópico, sobretudo dando ênfase às referências feitas no Contrato Social ao pensamento do escritor florentino, as quais fornecem pistas interessantes para investigar em que medida Rousseau teria incorporado ou rechaçado algumas das teses mais importantes de Maquiavel.

Começarei a apresentação abordando as ideias de Maquiavel. Em seus Discursos sobre a primeira década de Tito Livio, o autor teceu uma série de comentários sobre a história de Roma, ressaltando a formação e o desenvolvimento de suas principais instituiçôes políticas. No quarto capítulo da primeira parte, ele enfoca o tema das dissensóes internas da república para apresentar uma interpretação que divergia da visão corrente sobre o assunto. Assim, escreve Maquiavel:

Direi que quem condena os tumultos entre os nobres e a plebe parece censurar as coisas que foram a causa primeira da liberdade de Roma e considerar mais as assuadas e a grita que de tais tumultos nasciam do que os bons efeitos que eles geravam; e não consideram que em toda república há dois humores diferentes, o do povo, e o dos grandes; e que todas as leis que se fazem em favor da liberdade nascem da desunião deles, como facilmente se pode ver que ocorreu em Roma. (MAQUIAVEL, 2007, p. 21-22).

O filósofo já havia mencionado tais "humores" distintos em $O$ Príncipe, ${ }^{2}$ onde se lê que o povo tem o desejo de não ser governado nem oprimido pelos grandes, ao passo que estes são movidos pelo desejo de governar e oprimir o povo.

Maquiavel pensava que as dissensóes entre os patrícios e os plebeus ajudaram a república romana a chegar à perfeição, algo que se podia ver pela estabilidade de que ela desfrutou, ao longo de vários séculos. Como se tratava de um corpo político bem-ordenado, cujos cidadãos possuíam uma grande virtù nascida da boa educaçáo, os tumultos eram capazes de dar origem às leis garantidoras da liberdade. Nas ocasióes em que os grandes buscavam dar vazão a seu anseio de oprimir os plebeus, estes respondiam com atos que forçavam o governo a lhes conceder algo para satisfazê-los, assim como ocorreu na rebelião que levou à criaçáo dos tribunos da plebe. Para Maquiavel, os desejos dos povos livres, tais como os da plebe romana, dificilmente são perniciosos para a liberdade,

${ }^{2}$ Capítulo IX. 
pois eles vêm da suspeita de que se está sob o risco de cair na opressão. No caso do conflito que resultou na instituição do tribunato, o autor afirma que ele foi de grande auxílio para a república, ao dar à plebe sua parte na administraçáo pública, bem como por ter constituído bons guardióes para a liberdade ${ }^{3}$.

A partir das reflexóes de Maquiavel sobre o caso romano, é visível que o autor compreendia a esfera política como sendo atravessada por relaçóes de forças entre os diferentes grupos sociais, relaçôes que se modificam ao longo do tempo em função das possibilidades concretas de manifestação dos humores heterogêneos, o que leva a equilíbrios sempre transitórios entre as demandas de cada participante do confronto. Uma conclusão decisiva a se extrair disso, segundo José Luiz Ames, é a de que Maquiavel não concebia a política como um campo no qual a ordem e a desordem eram opostos mutuamente exclusivos, mas que ele estabeleceu entre ambas uma relação intrínseca, “[...] de tal maneira que uma pressupóe a outra” (AMES, 2010, p. 46).

Obviamente, não se deve enxergar nisso uma apologia do caos social, como se todos os tumultos presentes no Estado contribuíssem da mesma forma para a sua liberdade. Em $O$ Príncipe, o autor havia alertado para o fato de que os efeitos nascidos dos apetites distintos não incluíam apenas a liberdade, mas também o principado e a licença [licenzia]. ${ }^{4}$ Nos Discursos, ele ressalta que as divisóes internas da república romana contribuíam para a liberdade, porque ocorriam dentro de um ambiente político no qual havia instituiçôes reconhecidas como legítimas pelos cidadãos, as quais permitiam aos grupos em disputa canalizar seus anseios sem colocar em risco o próprio sistema. Se tais recursos não existissem, certamente seriam buscados meios extraordinários - entre eles a violência e as forças privadas - para que esses anseios se exprimissem, meios capazes de levar o Estado à ruína: "Por isso", assinala Maquiavel, "[...] nada há que torne mais estável e firme uma república

\footnotetext{
${ }^{3} \mathrm{~A}$ instituição do tribunato remonta, segundo a tradição, à revolta da plebe romana no ano de 493 a.C., quando ela se retirou para o Monte Sagrado e pressionou os patrícios até que concordassem em lhe conceder novos direitos. Com isto, foram criados os tribunos, cidadãos eleitos para representar os interesses da plebe. Os tribunos náo possuíam imperium nem potestas, mas tinham o poder de convocar os plebeus e falar a eles (ius agendi cum plebe), e, acima de tudo, podiam exercer o direito de veto (intercessio tribunicia) contra as outras magistraturas, contra os comícios e até contra o senado. Ao longo da história da república, os tribunos fizeram diversas reivindicaçōes em favor da plebe, tais como a codificação do direito costumeiro e a igualdade civil e política entre patrícios e plebeus. Declarados invioláveis (sacrosancti), eles eram protegidos de ataques por sançôes religiosas e civis. Entre seus poderes também estava o de prender e punir seus ofensores. Inicialmente, havia apenas dois tribunos de cada vez, mas o número aumentou até chegar a dez.
}

${ }^{4}$ Ver $O$ Príncipe, capítulo IX. 
do que ordená-la de tal modo que a alteração dos humores que a agitam encontre via de desafogo ordenada pelas leis" (2007, p. 33). ${ }^{5}$

Mantendo essas teses de Maquiavel em mente, podemos passar agora às ideias de Rousseau. Nesse sentido, é digno de nota que o filósofo de Genebra demonstrou publicamente sua admiração pelo autor de $O$ Príncipe, tendo ressaltado, no Contrato Social, que ele havia sido um homem honesto e um bom cidadão, cujo amor à liberdade e à causa republicana teve que ser disfarçado em uma cidade oprimida pelo governo dos Médici. ${ }^{6}$ Ao reconhecer o valor do pensamento político maquiaveliano, Rousseau o citou, por diversas vezes, como apoio para suas próprias proposiçôes, ${ }^{7}$ inclusive nos momentos em que lidou com o problema das divisôes sociais. Entretanto, a questão a se fazer é: até que ponto Rousseau realmente se aproximou de Maquiavel acerca desse tópico tão importante?

As primeiras pistas para responder a essa indagação encontram-se no capítulo do Contrato Social em que o autor aborda o que seria necessário para o predomínio da vontade geral nas deliberaçóes públicas, a saber, que o povo esteja suficientemente informado sobre a proposta a ser votada nas deliberaçóes e que os cidadãos não tenham comunicação entre si. ${ }^{8}$ Desse modo,

${ }^{5}$ Discursos, capítulo VII.

${ }^{6}$ Em um trecho do verbete sobre a Economia Politica escrito para a Enciclopédia, Rousseau chega a se referir às ideias contidas em $O$ Príncipe como dotadas de um tom satírico: "Então, seria apropriado dividir ainda a economia pública em popular e tirânica. A primeira é a de todo Estado no qual reina uma unidade de interesse e de vontade entre o povo e os chefes. A outra existirá necessariamente em todo lugar onde o governo e o povo tiverem interesses diferentes e, portanto, vontades opostas. As máximas da última estão registradas extensamente nos arquivos da história e nas sátiras de Maquiavel. As outras se encontram somente nos escritos dos filósofos que ousam reivindicar os direitos da humanidade" (ROUSSEAU, 2003, p. 247). No verbete sobre o Maquiavelismo, Diderot seguiu a mesma interpretação: "Quando Maquiavel escreveu o seu tratado do príncipe, é como se ele tivesse dito aos seus concidadáos: leiam bem esta obra. Se vocês aceitarem alguma vez um senhor, ele será como eu vo-lo retrato - eis a besta feroz à qual vos abandonareis. Assim, foi falha dos seus contemporâneos se eles năo perceberam o seu objetivo: eles tomaram uma sátira por um elogio" (DIDEROT, 1751, p. 793).

${ }^{7}$ Acerca de como Rousseau pode ter obtido seu primeiro conhecimento dos textos do secretário florentino, Maurizio Viroli dá algumas informaçōes relevantes: "É provável que Rousseau tenha lido Maquiavel durante o período de sua colaboração com os enciclopedistas. Além de sua influência na Economia Politica, há traços presentes no Discurso sobre a origem da desigualdade [...]. O nome de Maquiavel também aparece na Rainha Fantasiosa [...], uma obra à qual Rousseau referiu-se como 'uma ninharia' [...]. Há também outra possibilidade - a de que Rousseau poderia ter lido Maquiavel ainda quando estava vivendo em Genebra, durante sua infância. As obras de Maquiavel podiam ser encontradas na pequena biblioteca dos artesãos de Genebra que viviam próximos da família de Rousseau e com os quais ela tinha boas relaçôes [...]. Também sabemos que, entre 1610 e 1650, cinco ediçóes das obras de Maquiavel foram impressas em Genebra” (VIROLI, 2002, p. 168).

${ }^{8}$ Ver o Contrato Social, livro 2, capítulo III. 
do grande número de diferenças - os votos individuais - resultaria a vontade geral. Porém, logo na sequência, Rousseau alerta para o perigo das facçóes ou associaçôes parciais, cujos interesses particulares interferem negativamente no processo deliberativo, na medida em que eles reduzem o número de opinióes a serem contabilizadas nos sufrágios. Afinal, quando os cidadáos passam a integrar tais grupos, eles deixam de votar segundo sua própria perspectiva a respeito do que é o bem comum de todo o Estado, pois adotam a defesa do que é o melhor para a associação da qual fazem parte. Logo, propóe Rousseau, o ideal é que essas associaçóes não sejam admitidas no corpo político ou que sejam tão numerosas que sua força particular acaba se diluindo. ${ }^{9}$

No decorrer de sua argumentação, Rousseau cita um trecho da História de Florença escrita por Maquiavel (livro VII, capítulo 1), no qual estaria expressa uma concepção semelhante à dele:

É verdade que algumas divisóes prejudicam as repúblicas e outras as beneficiam. As prejudiciais são as que suscitam facçôes e partidários; as benéficas são as que se mantém sem facçôes e sem partidários. Portanto, não podendo o fundador de uma república evitar que as inimizades se manifestem nela, ao menos deve ordená-la de modo que não se formem facçôes" (MAQUIAVEL apud ROUSSEAU, 2003, p. 372).

Ora, um exame mais cuidadoso do que Maquiavel estava tratando, no contexto dessa citação, revela que o entendimento contido nele acerca das facções não é o mesmo que Rousseau pretende com a noção de associações parciais. Antes dessas linhas, é importante lembrar, o florentino contraria aqueles que acreditam ser possível uma república dotada de unidade. Não

${ }^{9} \mathrm{O}$ verbete sobre a Economia política já trazia uma advertência contra os problemas causados pelas associaçóes parciais. Para Rousseau, seus membros adquirem uma fidelidade ao grupo potencialmente nociva ao bem comum, pois um indivíduo pode ser um "[...] padre devoto, um soldado corajoso ou um médico zeloso e um mau cidadáo” (ROUSSEAU, 2003, p. 246). Assim, embora a vontade geral seja sempre a mais justa, "[n]ấo se segue por isso que as deliberaçóes públicas sejam sempre equitativas; [...] não é impossível que uma república bem governada faça uma guerra injusta. Também não é impossível que o conselho de uma democracia aprove maus decretos e condene os inocentes. Mas isso nunca acontecerá se o povo não for seduzido por interesses particulares que, com influência e eloquência, alguns homens engenhosos saberão colocar no lugar dos interesses populares. Entáo, uma coisa será a deliberação pública e outra será a vontade geral [...]. Examinai com cuidado o que se passa em uma deliberaçâo qualquer e vereis que a vontade geral é sempre favorável ao bem comum, mas muito frequentemente se faz uma cisão secreta, uma confederação tácita que por vias particulares desvia a disposiçáo natural da assembleia. Desse modo, o corpo social divide-se realmente em outros, cujos membros tomam uma vontade geral boa e justa em relação a esses novos corpos, injusta e má em relação ao todo do qual cada um deles se desmembra” (ROUSSEAU, 2003, p. 246-247). 
apenas as divisóes internas ao Estado são fenômenos próprios da ordem política, como podem se manifestar de modos diversos, pois os cidadãos buscam adquirir reputação e poder por caminhos diferentes. Alguns percorrem uma via pública para atingir esse objetivo, prestando serviços militares e governamentais, por exemplo. Outros seguem uma via privada que envolve fornecer apoio financeiro a determinadas pessoas, protegê-las das autoridades e elevá-las até honrarias não merecidas, ou ainda esbanjar dinheiro em jogos e entretenimentos públicos para ganhar o apoio do populacho. Assim, comenta Maquiavel, a influência obtida da primeira forma é fundada no bem público, ao passo que a segunda causa males ao Estado, por fomentar a corrupção e o surgimento de facçóes vinculadas a interesses particulares. Portanto, como as inimizades e as divisóes sociais sáo inevitáveis, é necessário fazer com que elas se manifestem de forma benéfica, porque, quando os cidadãos disputam entre si o sucesso por meio da via pública, isso promove a exaltação da pátria e faz com que uns observem a conduta dos outros e mantenham suas querelas dentro dos limites da ordem civil. ${ }^{10}$

Se voltarmos ao texto dos Discursos, encontraremos uma análise do tipo de divisão social que mais prejudica o Estado, tal como Maquiavel viu os acontecimentos do final da república romana. No capítulo 37 da Primeira Parte, ele alude às disputas relativas à distribuição de terras entre os cidadãos que acabaram suscitando verdadeiras guerras civis entre facçôes opostas, as quais culminaram na tirania de Júlio César. Nessa conjuntura, afirma o filósofo, “[...] visto que os magistrados públicos não podiam remediar a situação, e como nenhuma das facçóes depositasse esperança neles, recorreuse a remédios privados, e cada uma das partes tratou de constituir um cabeça que a defendesse" (MAQUIAVEL, 2007, p. 115). ${ }^{11}$ Tamanho era o ódio entre o senado e a plebe, que os atos de seus respectivos líderes - Mário e Sila, primeiramente, César e Pompeu, num segundo momento - produziram

${ }^{10}$ Nos Discursos (terceira parte, capítulo 28), tais ideias também estão presentes, quando Maquiavel examina o caso de Espúrio Mélio, um romano que usou sua fortuna para alimentar a plebe, em uma época de escassez. Como isso lhe deu uma influência muito grande sobre o povo, o Senado instituiu um ditador para julgá-lo e condená-lo à morte, temendo que Mélio viesse a usar esse poder contra as autoridades instituídas. Diante disso, Maquiavel chama a atenção para certos atos aparentemente praticados de boa fé e que podem colocar em risco a república, se não forem devidamente corrigidos. Ele propóe que as coisas sejam reguladas de modo que a reputação obtida pelos cidadãos não resulte em tirania, mas seja benéfica ao Estado, tal como acontece quando eles seguem a via pública descrita na História de Florença. Os romanos fizeram isso instituindo prêmios para os que realizavam algo de destaque em favor da cidade (os triunfos dos generais vencedores, por exemplo), bem como as acusaçóes contra os que utilizavam meios privados para de engrandecer.

${ }^{11}$ Discursos, capítulo XXXVII. 
levantes armados e muito derramamento de sangue, cujo resultado foi a perda definitiva da liberdade de Roma. Para Maquiavel, isso náo refuta o que ele havia proposto antes, porque, se a enorme ambição dos patrícios não tivesse sido contida pelo desejo do povo de não ser oprimido desde os primórdios da cidade, o que se testemunhou no derradeiro século do regime republicano teria ocorrido bem mais cedo. $\mathrm{O}$ grande erro dos romanos nessa época foi o de ter empregado sucessivamente meios extraordinários para solucionar suas querelas, o que resultou em um facciosismo táo grave que colocou em xeque a capacidade do poder público de promover um acordo satisfatório entre os partidos. Ao invés de apenas querer evitar a opressão dos grandes, o povo desejou ele mesmo oprimi-los, ultrapassando assim as características de seu humor específico e instaurando um desequilíbrio bastante perigoso nas relaçóes de força, ao fazer com que certos indivíduos tivessem uma predominância indevida dentro do Estado ${ }^{12}$.

Comparando essa descrição maquiaveliana das facçóes com o tema das associaçôes parciais mencionadas no Contrato Social, podemos perceber as diferenças em suas perspectivas. Como foi visto, essas associaçôes parciais são basicamente grupos com um interesse próprio, cuja presença prejudica a enunciação da vontade geral, por não deixar que cada indivíduo vote de acordo com sua opiniáo pessoal. Conforme esclarece Lionel A. McKenzie, quando o autor do Contrato Social cita Maquiavel como suporte à sua tese, ele faz parecer que a afirmação do florentino

[...] refere-se às divisóes entre indivíduos, "as muitas pequenas diferenças" dentro do corpo coletivo de cidadáos que Rousseau tinha em mente. Além disso, porque Rousseau não examinou a definição de facção de Maquiavel, somos encorajados a presumir que Maquiavel teria desaprovado igualmente as divisōes na forma de grandes associaçôes parciais. (MCKENZIE, 1982, p. 219).

Todavia, complementa McKenzie, lida em seu contexto, a citação mostra que tal suposição seria falsa:

\footnotetext{
12 "Enquanto o conflito permanece de tal modo que o povo consegue deter a tendência dos grandes ao exercício da dominação ilimitada e os grandes são capazes de impedir o povo de estabelecer uma situaçẫo de absoluta liberdade, ele engendra um vivere civile; quando, porém, um humor chega até o seu próprio termo e se completa plenamente, ou quando um humor renuncia à sua singularidade para colocar-se no lugar do outro, transforma seu objetivo último e se identifica com o humor oposto, a Cidade é atravessada por um conflito de natureza diversa, que, em vez de engendrar um vivere civile, na realidade o destrói” (AMES, 2010, p. 53).
} 
As divisões entre os cidadãos, quando agrupados em torno de homens de virtù, podiam realmente servir para manter as liberdades de uma república por meio da vigilância mútua. $\mathrm{O}$ sucesso disso dependia da natureza das divisóes em si. Maquiavel reservou a palavra "facção" para descrever as divisóes constituídas por meio da corrupção política. A esse respeito, ele e Rousseau estavam em clara concordância. Sua concordância termina quando Rousseau visualizou uma associação política legítima na qual os indivíduos isolados tomam decisóes sobre o bem público, ao passo que Maquiavel concebeu uma na qual os indivíduos competem entre si e tornam-se os líderes de um conflito saudável. (MCKENZIE, 1982, p. 219-220).

Esse contraste efetuado por McKenzie leva a conclusões bastante sérias sobre as concepçôes de política nutridas por Maquiavel e Rousseau. Se o autor dos Discursos nos oferece um entendimento das relaçóes entre os componentes da sociedade como algo que se expressa por conflitos essenciais para o funcionamento de um Estado bem-ordenado, isto é, conflitos que emergem dos desejos distintos quanto ao exercício do poder, Rousseau dirige-se para outra direção, ao insistir na união das vontades dos cidadãos como requisito imprescindível a um Estado onde a liberdade seja viável. Esse ideal republicano aparece nitidamente no primeiro capítulo do livro 4 do Contrato Social:

Enquanto muitos homens reunidos se consideram como um só corpo, eles têm uma única vontade que se refere à conservação comum e ao bemestar geral. Então, todos os móveis do Estado são vigorosos e simples, suas máximas são claras e luminosas, não há interesses confusos e contraditórios, o bem comum mostra-se por toda parte com evidência e exige apenas bom senso para ser percebido. (ROUSSEAU, 2003, p. 437).

Nesse contexto, poucas leis bastariam para governar o povo, e sempre que alguma mudança fosse necessária, todos sentiriam isso facilmente e o acordo nas deliberaçôes passaria longe das intrigas e dos duelos de eloquência. ${ }^{13}$ Certamente, seria possível afirmar que esse quadro representa o grau máximo

${ }^{13}$ De acordo com Claudio Araújo Reis, “[o] processo deliberativo, segundo Rousseau, é menos uma troca pública e coletiva de razóes e argumentaçôes do que uma consulta individual à consciência. Ouvir a voz da consciência, que é um sentimento e está sempre voltada para o bem, é o ponto fundamental. Lembremos que mais de uma vez Rousseau explicita sua falta de gosto pelos debates, pelas discussóes públicas. O processo pelo qual se chega à declaração da vontade geral (pelo qual tomamos uma decisão coletiva) não é essencialmente um processo de troca de razóes nem, muito menos, um processo de barganha, de negociação, de acomodação de interesses (o que tende, como bem viu Rousseau, a ser agravado por uma política de facçóes, de partidos, que fatalmente dirigem o jogo político em direção à competiçẫo e não à cooperação)" (REIS, 2010, p. 23). 
de unidade civil, o ponto mais alto na escala dos princípios do direito político contidos na obra do filósofo, e que os Estados concretos jamais atingiriam tal perfeição. No entanto, ainda assim essa imagem de comunhão entre os membros do pacto social é um parâmetro fundamental para se julgar a qualidade das práticas políticas de quaisquer Estados. Quanto mais elas se afastam do padrão de referência, menores são as chances de que se tenha uma república bemordenada, como o próprio Rousseau deixa claro, ao criticar os males advindos do afrouxamento dos laços sociais. $\mathrm{Na}$ medida em que a uniáo do Estado se enfraquece, os interesses particulares tornam-se influentes e as pequenas associações - isto é, as facçóes ou associaçóes parciais - interferem cada vez mais nos rumos tomados pela comunidade, de forma que "[...] o interesse comum se altera e encontra opositores, a unanimidade não reina mais nos votos, a vontade geral não é mais a vontade de todos, surgem contradições, debates, e a melhor opinião não é aprovada sem disputas" (ROUSSEAU, 2003, p. 438).

Os termos "unanimidade" e "vontade de todos", presentes nessa citação, exigem alguns comentários. Em outro ponto do Contrato Social ${ }^{14}$, Rousseau ressalta que apenas o pacto social é uma lei, que, por sua própria natureza, demanda o consentimento unânime, pois os que não a aprovam ficam excluídos do Estado que ela institui. Nesse sentido, para as outras leis, vale a regra da maioria. Ademais, há o trecho bastante conhecido da obra no qual ele escreve: "Frequentemente, existe muita diferença entre a vontade de todos e a vontade geral; esta só observa o interesse comum, a outra observa o interesse privado e é apenas uma soma de vontades particulares" (ROUSSEAU, 2003, p. 371$)^{15}$. Diante disso, teríamos uma contradiçáo nas ideias do autor? Não me parece o caso. Precisamos atentar para a palavra que abre a citação, ou seja, "frequentemente". O que Rousseau nos aponta é que, embora seja comum encontrarmos divergências entre a vontade de todos e a vontade geral,

[...] tal disparidade não é necessária, mas contingente. Essas duas vontades se distanciam frequentemente porque a maioria dos povos não vive sob as condiçôes de legitimidade política descritas no Contrato Social, pois na maior parte dos Estados a ausência da virtude cívica permite que o interesse coletivo seja sobrepujado pelos interesses privados. Nos Estados bem constituídos, em contrapartida, existiria uma convergência entre a vontade de todos e a vontade geral, porque neles vigoraria uma harmonia entre os interesses particulares e o coletivo. Tudo depende, então, do

\footnotetext{
${ }^{14}$ Livro 4, capítulo 2.

${ }^{15}$ Contrato Social, livro 2, capítulo III.
} 
quanto o bem público é uma preocupação genuinamente difundida entre os cidadãos. (MOSCATELI, 2010, p. 92). ${ }^{16}$

$\mathrm{Na}$ discussão sobre os sufrágios, Rousseau retoma a questão da unanimidade, de modo a reiterar sua importância como padrão de referência. Para ele, a observação do tratamento dado aos assuntos públicos fornece indícios bastante seguros sobre o estado dos costumes e da saúde de um corpo político: "Quanto mais a concórdia reina nas assembleias, quer dizer, quanto mais as opinióes se aproximam da unanimidade, mais também a vontade geral é dominante. Porém, os longos debates, as dissensôes e o tumulto anunciam a ascendência dos interesses particulares e o declínio do Estado" (ROUSSEAU, 2003, p. 439). Mais adiante, ele reconhece que, dadas as circunstâncias concretas de cada república, não se pode requerer votações unânimes em todos os casos. No entanto, nas deliberaçôes sobre as questôes mais importantes, ou seja, aquelas decisôes tomadas pelo soberano no tocante às leis, a máxima geral a ser seguida é a de se exigir um resultado tão próximo da unanimidade quanto for possível. Assim, num Estado bem-ordenado, a vontade geral precisaria ser, se não a vontade de todos, pelo menos de quase todos, para que as condiçóes necessárias à legitimidade política estejam presentes ${ }^{17}$.

É interessante notar que, em meio a essa argumentação, Rousseau recorre ao exemplo de Roma para expor suas ideias, tal como Maquiavel, e nesse momento ele se vê forçado a reconhecer a existência daquelas dissensóes internas que o florentino havia enfocado nos Discursos. Entretanto, segundo Rousseau, essa admissão não invalidava sua própria tese sobre a unidade política como sinal da saúde do Estado. Para demonstrar isso, ele começa afirmando

${ }^{16}$ Tanto é assim que, em outros momentos além do livro 4 do Contrato Social, Rousseau também usou a expressão "vontade de todos" no lugar de "vontade geral". Ver o verbete sobre a Economia política: "É apenas à lei que os homens devem a justiça e a liberdade. É esse órgáo salutar da vontade de todos que restabelece, no direito, a igualdade natural entre os homens" (ROUSSEAU, 2003, p. 248) excerto incluído novamente no Manuscrito de Genebra, livro 1, capítulo VII; e as Cartas escritas da montanha, sexta carta: "A vontade de todos é, portanto, a ordem, a regra suprema, e essa regra geral e personificada é o que eu chamo de soberano" (ROUSSEAU, 2003, p. 807).

${ }^{17}$ No verbete sobre a Economia política, fica evidente o papel crucial da virtude cívica para o bom ordenamento da república. Rousseau questiona: "Quereis que a vontade geral se realize? Fazei com que todas as vontades particulares se relacionem a ela; e como a virtude é somente essa conformidade da vontade particular à vontade geral, para dizer a mesma coisa resumidamente, fazei reinar a virtude" (ROUSSEAU, 2003, p. 252). Pouco depois, ele reforça sua tese, propondo que o meio mais eficaz de levar os cidadáos a agir bem é inspirar neles o amor pela pátria, pois "[...] todo homem é virtuoso quando sua vontade particular está de acordo com a vontade geral, e nós desejamos de bom grado aquilo que desejam as pessoas de quem gostamos" (ROUSSEAU, 2003, p. 254). 
que o povo romano era dividido em duas ordens, a dos patrícios e a dos plebeus, e que as querelas entre elas frequentemente perturbaram o funcionamento das assembleias populares, inclusive nos tempos áureos da república. Dessa forma, continua Rousseau, esse vício inerente ao corpo político fazia com que Roma contivesse dois Estados em um. Embora as relaçôes entre essas duas ordens fossem conflituosas, no interior de cada uma reinava aquela concórdia típica de uma república bem-ordenada, o que se via nos plebiscitos realizados pelo povo, pois, “[...] quando o senado não se imiscuía neles", escreve o autor, "[...] eram aprovados sempre tranquilamente e com grande pluralidade de votos. Os cidadãos tendo apenas um único interesse, o povo tinha somente uma vontade" (ROUSSEAU, 2003, p. 439). Rousseau procura mostrar que Roma parecia ser uma exceção ao que ele havia defendido, mas que, na verdade, ela confirmava sua tese. Apesar de seu "vício inerente", essa república foi capaz de servir de exemplo a todos os povos livres. ${ }^{18}$

Ora, como sugere McKenzie, ao adotar essa estratégia argumentativa, Rousseau evitou entrar em choque aberto com a interpretaçáo maquiaveliana da história de Roma. Para não ter de refutar diretamente a ideia de que as dissensóes entre os patrícios e a plebe foram a causa das boas leis e da liberdade da república, o genebrino teria usado termos anacrônicos para descrever a organização da sociedade romana. Assim, escreve McKenzie:

A referência a "ordens" e à existência de dois "Estados" em um foi calculada para trazer às mentes de seu público as ordens e os Estados do Antigo Regime, em vez da existência dos interesses sociais amplamente opostos que a análise de Maquiavel identificou. O conteúdo social dos termos de Maquiavel foi então obscurecido ao ser confundido com os termos relacionados às categorias legais da sociedade francesa. (MCKENZIE, 1982, p. 221).

A refutação da tese dos Discursos por Rousseau, conclui o comentador, “[...] era arbitrária no sentido de que a generalização de Maquiavel tentava expressar uma teoria da dinâmica do conflito social e político, e as possibilidades legítimas que tais conflitos abriam" (MCKENZIE, 1982, p. 221). Portanto, o quadro rousseauniano se afasta do maquiaveliano, por minimizar a relevância das tensóes sociais em Roma e ressaltar a concórdia que existia no interior das duas partes do povo. Fazendo esse deslocamento, Rousseau pôde sustentar que

\footnotetext{
${ }^{18} \mathrm{Um}$ modelo difícil de ser igualado, é verdade, pois "Roma foi, durante quinhentos anos, um milagre contínuo que o mundo não deve mais esperar ver novamente" (ROUSSEAU, 2003, p. 262), como o filósofo ressaltou, no verbete sobre a Economia política.
} 
“[...] o que não é verdade acerca dos dois [Estados] em conjunto, é verdade acerca de cada um separadamente" (ROUSSEAU, 2003, p. 439). Como ele não se deu o trabalho de analisar com mais cuidado a relação conflituosa entre patrícios e plebeus, não chegou a fornecer uma explicação adequada das motivaçóes de suas querelas, ${ }^{19}$ ao contrário de Maquiavel, que as atribuiu aos humores políticos heterogêneos dos grandes e do povo. ${ }^{20}$

${ }^{19} \mathrm{Na}$ análise de McKenzie, "[t]anto Rousseau quanto Machiavel encontraram uma verificação empírica de suas teorias divergentes sobre o direito político na história da república romana apenas porque suas interpretaçōes diferiam. [...] Maquiavel fez da república romana o caso paradigmático de uma sociedade que atingiu a liberdade por meio do conflito. Rousseau aventurou-se, em vez disso, a transformá-la no modelo histórico de uma sociedade unida, harmoniosa e livre" (1982, p. 227).

${ }^{20}$ Ainda sobre a história de Roma, há outra menção feita no Contrato Social que merece alguns comentários. No capítulo sobre a degeneração do governo (livro 3, capítulo X), Rousseau explica que há uma tendência inerente ao corpo político pela qual os governantes agem continuamente contra a soberania popular, o que resulta, em última instância, na destruiçấo da república. Ele acrescenta que existem dois caminhos que levam a isso, a saber, a contração do governo - diminuição do número de seus membros - e a dissoluçáo do Estado - usurpaçáo do poder soberano pelo príncipe. A fim de exemplificar empiricamente sua teoria, Rousseau incluiu uma nota na qual expôs sua visão sobre o desenvolvimento das instituiçôes políticas romanas. Para ele, após a expulsão dos reis e a instituição da república, o ordenamento da cidade permaneceu instável durante algum tempo, devido ao conflito entre a aristocracia hereditária e as tendências democráticas já presentes. Foi apenas com a criaçáo dos tribunos da plebe, sustenta o autor, baseando-se na autoridade de Maquiavel, que a forma do governo se fixou em uma verdadeira democracia. Nessa fase, o povo era soberano, magistrado e juiz, e os patrícios tinham de se curvar às decisóes populares. Contudo, prossegue Rousseau, o movimento natural de contraçáo do governo verificou-se com a passagem a uma aristocracia concentrada no senado, órgão composto não somente de patrícios, mas também de plebeus. Além disso, os tribunos integravam tal aristocracia, na medida em que tinham usurpado um poder mais ativo na condução dos negócios públicos. O próximo passo nesse processo ocorreu depois das guerras civis do último século a.C., as quais levaram ao surgimento do poder monárquico de Sila, César e Augusto, até que, por fim, o Estado se dissolveu sob o despotismo de Tibério. A leitura dessas páginas do Contrato Social revela pelo menos dois problemas importantes. O primeiro consiste na afirmação de que a instituição do tribunato teria gerado uma democracia capaz de resolver os conflitos entre os patrícios e a plebe, uma tese em apoio da qual Rousseau evoca o nome de Maquiavel. Na verdade, tal como foi já foi destacado, o escritor florentino propôs que o estabelecimento dos tribunos deu à plebe sua parte no poder e conferiu estabilidade ao regime, tornando-o uma república mista com elementos monárquicos, aristocráticos e democráticos ou, para usar os próprios termos de Maquiavel, uma república que combinava os três tipos de Estados: o principado, o dos optimates e o popular. Outro ponto fundamental que Rousseau não menciona é que, para Maquiavel, a república romana atingiu a perfeição graças à desunião entre a plebe e o senado, cujos humores distintos continuaram produzindo tumultos, ao longo de todos os séculos seguintes. Conforme o autor dos Discursos, os tribunos assumiram o papel de guardiōes da liberdade em Roma, mas não fizeram isso, pondo um término aos conflitos entre os grandes e o povo, por meio da democracia. Quanto ao segundo problema na argumentação rousseauniana, ele está na falta de articulação entre essa descrição geral da história do governo romano e aquela já analisada, segundo a qual havia dois Estados diferentes dentro da república - o dos patrícios e o dos plebeus. Afinal, em que momento exatamente esses Estados coexistiram? Talvez somente na época democrática, pois, na fase aristocrática, Rousseau assevera que a elite dominante era uma mescla de patrícios e plebeus, ficando então difícil falar de 
Um problema semelhante aparece no capítulo do Contrato Social cujo tema reside nos sinais de um bom governo. ${ }^{21}$ Após argumentar que o critério mais adequado para avaliar se o Estado é ou não bem administrado consiste no crescimento populacional, visto que isso denota a existência de condições políticas propícias à conservação e à prosperidade dos cidadãos, Rousseau acrescenta uma nota na qual discute algumas objeçóes históricas que poderiam ser levantadas contra o critério proposto. De acordo com ele, deve-se olhar não para as situaçóes pontuais de calamidade ou felicidade nos Estados, mas para as condições de longo prazo nas quais os povos vivem. Dessa maneira, pode-se compreender, por exemplo, que os franceses estivessem felizes e numerosos, mesmo durante os tumultos da Fronda, no século XVII, e que a Grécia tenha florescido em meio às guerras cruéis da Antiguidade. Por fim, ele parafraseia um trecho do prefácio da História de Florença:

Parece, diz Maquiavel, que no meio dos assassinatos, das proscriçóes, das guerras civis, nossa república tornou-se mais poderosa. A virtude de seus cidadãos, seus costumes, sua independência tinham mais efeito para reforçála do que todas as suas dissensôes o tiveram para enfraquecê-la. Um pouco de agitação dá energia às almas, e o que faz verdadeiramente prosperar a espécie é menos a paz do que a liberdade. (ROUSSEAU, 2003, p. 420).

Ora, mais uma vez, Rousseau evoca Maquiavel para amparar suas ideias, e novamente é necessário buscar o que o próprio florentino escreveu, para verificar se isso faz sentido.

No início da História de Florença, o autor expôe sua tese sobre as divisões internas que fazem parte das repúblicas e podem favorecê-las ou destruí-las, conforme as circunstâncias envolvidas. Em seguida, ele assinala que o caso de Florença era ainda mais complicado, porque a cidade teve diferentes divisóes, ao longo dos séculos: primeiro, dentro da nobreza, depois, entre os nobres e o povo,

duas ordens distintas dentro da sociedade. Tal como McKenzie sublinha (1982, p. 222), Rousseau não apenas interpretou mal o texto de Maquiavel a respeito dessas questôes, como também trouxe para si uma série de incoerências, ao citá-lo sem resolver os problemas que ele levantou. Ainda nesse sentido, é necessário apontar que a concepção dos dois pensadores acerca da função do tribunato também divergia. Se Maquiavel viu nos tribunos aqueles que representavam a plebe e a defendiam frente aos patrícios, Rousseau considerava que o tribunato deveria ser reformulado, para servir à república como um todo, isto é, equilibrando as relaçôes entre o soberano, o governo e o povo, de modo a proteger a ordem constitucional. A esse respeito, ver o Contrato Social, livro 4, capítulo V.

${ }^{21}$ Livro 3, capítulo IX. 
e, enfim, entre o povo e a plebe. ${ }^{22}$ Os resultados dessas dissensóes foram mais mortes, exílios e famílias destruídas do que em qualquer outra cidade. Todavia, afirma Maquiavel, a força de Florença se mostrou justamente em ter prosperado mesmo em meio a esses problemas, pois a virtù e as demais qualidades de muitos de seus cidadãos permitiram que eles contribuíssem para o engrandecimento de sua pátria. Consequentemente, percebe-se que Maquiavel enxerga a história de sua cidade como tendo sido atravessada por conflitos recorrentes e danosos ao bem público, pois essas inimizades eram sempre partidárias e resultavam em combates armados; elas náo consistiram em fenômenos isolados, mas em algo constitutivo da realidade política florentina. ${ }^{23}$

Se confrontarmos essas constataçóes com o texto do Contrato Social, veremos que Rousseau parece estar dando razão à tese maquiaveliana sobre a relação entre a liberdade e as divisóes sociais. Porém, temos de lembrar o que ele escreveu exatamente, ou seja: "Um pouco de agitação dá energia às almas". Com efeito, o relato de Maquiavel sobre sua cidade revela que os conflitos ocorridos nela estavam longe de ser uma "pequena agitação", de tal modo que a paráfrase feita por Rousseau acaba por amenizar as consequências que se poderiam tirar da História de Florença. Ademais, Rousseau não chega a indicar a pátria de Maquiavel como um exemplo de Estado a ser seguido. Caso o fizesse, teria que explicar melhor por que uma república táo marcada por disputas acirradas entre facçôes e com tantos episódios de violência entre seus cidadãos poderia ser digna de elogios. ${ }^{24}$ Logo, apesar da afirmação de que a prosperidade da espécie é mais favorecida pela liberdade do que pela paz, seria incorreto deduzir que Rousseau estivesse realmente concordando com a doutrina exposta nos Discursos. ${ }^{25}$ Ele até

${ }^{22}$ Segundo esclarece uma nota de Nelson Canabarro, na História de Florença, Maquiavel usa a palavra "povo" (popolo) para se referir apenas aos empresários, negociantes e artífices da cidade que geriam seus próprios negócios (ver MAQUIAVEL, 1998, p. 32).

${ }^{23}$ A esse respeito, é interessante o contraste feito pelo autor (no livro 3 da História de Florença) entre as divisões que existiam na república romana e as que atravessaram sua cidade. Se as dissensōes de Roma conseguiam se resolver com discussão e pela lei, as de Florença acabavam em combates, mortes e exílios. Consequentemente, a virtù militar da primeira aumentava ao longo desses conflitos, ao passo que a de Florença se extinguia por causa deles. O grande problema consistia em que a inimizade entre o povo e os nobres florentinos era tâo grande que aquele não aceitava dividir o poder com estes. Dessa forma, escreve Maquiavel, "[...] o desejo do povo florentino era injurioso e injusto, por isto a nobreza com maiores forças às suas defesas se preparava, e assim ao sangue e ao exílio dos cidadãos se chegava; e as leis que depois se criavam, não à utilidade pública, mas ao vencedor todas beneficiavam” (MAQUIAVEL, 1998, p. 143).

${ }^{24}$ Justo ele que associou o pequeno número de crimes ao bom governo da sociedade. Ver o Contrato Social, livro 2, capítulo V.

${ }^{25}$ Quanto ao motivo que levou Rousseau a se esforçar tanto para convencer seus leitores acerca da concordância entre as ideias contidas no Contrato Social e as defendidas por Maquiavel, McKenzie 
garante que os tumultos e as guerras civis assustam muito os governantes, "[...] mas não fazem as verdadeiras infelicidades dos povos, os quais podem, inclusive, ter um descanso enquanto se disputa sobre quem os tiranizará" (ROUSSEAU, 2003, p. 420); todavia, como é bem visível, trata-se de dissensōes ocorrendo não em um regime republicano, mas em um quadro de ilegitimidade política no qual as discórdias entre os aspirantes a tirano desviariam momentaneamente a violência exercida contra os populares.

Como foi mencionado, quando se dedica a descrever o que seria um regime republicano digno desse nome, Rousseau dá um peso enorme à coesão social que deveria caracterizá-lo, à paz e à união entre seus membros. Mesmo para seus compatriotas, cujos sérios problemas políticos são denunciados nas Cartas escritas da montanha, ele não recomenda a rebeliáo contra os opressores que haviam tomado conta do governo de Genebra, porém, um esforço para acabar com as divisôes que opunham os cidadãos. $\mathrm{Na}$ conclusão da obra, insiste em que a concórdia era o melhor remédio para evitar que as dissensões internas acarretassem a perda da frágil liberdade que ainda restava na cidade. Num tom que beira o conformismo, ele se dirige aos genebrinos: "[...] a escolha do partido que tomareis não é a maior questão: ainda que essa escolha seja má em si, fazei-a todos juntos; por essa única razão ela se tornará a melhor, e fareis sempre o que se deve fazer, desde que o façais de comum acordo" (ROUSSEAU, 2003, p. 897). ${ }^{26}$

sugere uma hipótese. Para o comentador, ainda que tal concordância seja ilusória, é possível que a tentativa de construí-la demonstre o desejo de Rousseau de filiar-se ao campo republicano, uma tradição de pensamento político da qual o genebrino foi o principal expoente, no séc. XVIII. Isso explicaria por que ele recrutou Maquiavel como um aliado para fortalecer sua própria posição, mesmo que à custa de uma interpretação questionável da obra do autor dos Discursos.

${ }^{26} \mathrm{O}$ desejo de ver a tranquilidade preponderar em Genebra remete ao retrato idílico da Suíça de outrora, esboçado por Rousseau no Projeto de constituição para a Córsega: "A concórdia e a paz reinavam sem esforço em suas famílias numerosas, e elas quase só tinham que tratar entre si a respeito de casamentos nos quais apenas a inclinação era consultada, a qual não era formada pela ambição nem era detida pelos interesses e pela desigualdade. Esse povo pobre, mas que não passava necessidades, se multiplicava assim na mais perfeita independência, em uma uniáo que nada podia alterar; não havia virtudes porque, não tendo vícios para superar, fazer o bem nada lhe custava, e ele era bom e justo mesmo sem saber em que consistiam a justiça e a virtude. Da força com a qual essa vida trabalhosa e independente ligava os suíços à sua pátria resultavam os dois maiores meios usados para defendê-la, a saber, o concerto nas resoluçôes e a coragem nos combates. Quando se leva em conta a uniâo permanente que reinava entre homens sem senhores, quase isentos de leis, e que os príncipes vizinhos se esforçavam para dividir mediante todas as manobras da política; quando se vê a firmeza inabalável, a constância, a determinaçáo que esses homens terríveis levavam aos combates, decididos a morrer ou vencer e sem alimentar sequer a ideia de distinguir a sua vida da liberdade, não se terá dificuldade em imaginar os prodígios que fizeram para defender o seu país e a sua independência [...]. Este é o modelo que os corsos devem seguir para retornar à sua situação original" (ROUSSEAU, 2003, p. 914-915). 
Enfim, antes de concluir esta exposição, é importante assinalar que Rousseau também reconheceu que, além da concórdia reinante em um Estado bem-ordenado, há aquela que se impóe por meio da força de um governo autoritário usurpador da soberania popular. No caso de Roma, ele concebe que isso se deu sob o domínio dos imperadores, o qual representa a "outra extremidade do círculo" onde "[...] a unanimidade retorna. É quando os cidadãos, caídos na servidão, não têm mais liberdade nem vontade. Então, o medo e a adulação transformam os sufrágios em aclamaçóes; não se delibera mais, adora-se ou amaldiçoa-se" (ROUSSEAU, 2003, p. 439). Essas linhas trazem à memória o Segundo Discurso, obra em que Rousseau contrapóe a igualdade natural que existia entre os indivíduos antes do estabelecimento das sociedades, por um lado, ao grau último da desigualdade que se atinge sob o despotismo, por outro. Esse momento final é "[...] o ponto extremo que fecha o círculo", um novo estado de natureza corrompido onde "todos os particulares se tornam iguais porque não são nada e os súditos não têm outra lei exceto a vontade do senhor" (ROUSSEAU, 2003, p. 190). Tal como se verifica no Emílio, se há paz nessas condições, ela não passa da "[...] tranquilidade da morte; ela é mais destrutiva do que a própria guerra” (ROUSSEAU, 1980, p. 633), o que soa como uma advertência de que a paz dentro da sociedade também pode ser o sintoma de algo negativo, caso seja o fruto da degeneração do corpo político. Assim, se recorrermos novamente à ideia de que os princípios do Contrato Social são uma escala para avaliar a legitimidade dos Estados, ${ }^{27}$ encontraremos em suas extremidades dois momentos opostos da manifestação da unanimidade: um, no qual ela é o grau máximo de coesão de um povo livre, cuja vontade geral é o guia de cada um de seus membros; o outro, no qual ela é a eliminação de qualquer resquício da liberdade, quando nada mais resta senáo acatar pacificamente as ordens do déspota. É dentro desses limites, portanto, que reside todo o espaço da ação política possível.

MOSCATELI, Renato. Machiavelli versus Rousseau: the social divisions and their role in a well-ordered republic. Trans/Form/Ação, Marília, v. 38, p. 121-138, 2015. Edição Especial.

\begin{abstract}
The conflictual relations between social groups constitute an important topic for political philosophy, and the different ways in which they are interpreted depend on a broader view of the appropriate conditions for a well-ordered state. Machiavelli, for example, by reflecting on the case of Ancient Rome, sought to refute those who condemned the tumultuous conflicts between the nobles and the plebs of the city as if they had only caused harm to the Republic. For this author, these tumults were
\end{abstract}

${ }^{27}$ Como se vê no livro 5 do Emílio. 
among the main causes of Roman freedom, since the difference in the "humours" of the great and the people led to clashes that gave birth to laws favorable to freedom. Rousseau, for his part, described the existence of "private associations" within civil society as something potentially harmful to the harmony of the Republic, because each of them had a self-interest that was able to override the common good in public deliberations and jeopardize the prevalence of the general will. For Rousseau, the occurrence of long debates and tumults in the popular assemblies could also be a sign of internal divisions capable of causing the ruin of the state. In the face of these two ways of conceiving the political role of social conflicts, the goal of this article is to make a comparative analysis of Machiavelli's and Rousseau's ideas.

KEYWORDS: Machiavelli. Rousseau. Republic. Social conflicts.

\section{REFERÊNCIAS}

AMES, José Luiz. A lógica do heterogêneo e a liberdade republicana em Maquiavel. In: MARTINS, José Antônio. Republicanismo e democracia. Maringá: Eduem, 2010. p. 35-57.

DIDEROT, Denis. Machiavéllisme. In: Encyclopédie. 1. ed. 1751. Tomo 9. p. 793. Disponível em: <http://fr.wikisource.org/wiki/Page:Diderot_-_Encyclopedie_1ere_ edition_tome_9.djvu/793>. Acesso em: 11 maio 2013.

MAQUIAVEL, Nicolau. História de Florença. Tradução de Nelson Canabarro. 2. ed. São Paulo: Musa, 1998.

. O príncipe. Trad. José Antônio Martins. São Paulo: Hedra, 2007.

. Discursos sobre a primeira década de Tito Livio. Tradução de Martins Fontes. São Paulo: Martins Fontes, 2007.

MCKENZIE, Lionel A. Rousseau's debate with Machiavelli in the Social Contract. Journal of the History of Ideas, v. 43, n. 2, p. 209-228, abr.-jun. 1982.

MOSCATELI, Renato. Rousseau frente ao legado de Montesquieu: história e teoria política no Século das Luzes. Porto Alegre: EDIPUCRS, 2010.

REIS, Claudio Araújo. Vontade geral e decisão coletiva em Rousseau. Trans/Form/Ação, Marília, v. 33, n. 2, p. 11-34, 2010.

ROUSSEAU, Jean-Jacques. Euvres complètes. Paris: Gallimard, 2003. v. 3.

. Euvres complètes. Paris: Gallimard, 1980. v. 4.

VIROLI, Maurizio. Jean-Jacques Rousseau and the "well-ordered society". Tradução de Derek Hanson. Cambridge: Cambridge University Press, 2002.

Recebido / Received: 15/04/2015

Aprovado / Approved: 24/06/2015 
MOSCATELI, R. 